\title{
geografia
}

\section{Pembangunan android dalam menyokong pengajaran dan pembelajaran Geografi: Kajian kes GeoSudut}

\author{
${ }^{1}$ Nasir Nayan, ${ }^{1}$ Hanifah Mahat, ${ }^{1}$ Mohmadisa Hashim, ${ }^{1}$ Yazid Saleh, ${ }^{2}$ Edi Kurniawan, ${ }^{3}$ Nursida Arif \\ ${ }^{1}$ Jabatan Geografi dan Alam Sekitar, Fakulti Sains Kemanusiaan, Universiti Pendidikan Sultan Idris \\ ${ }^{2}$ Fakultas Ilmu Sosial, Universitas Negeri Semarang, Sekaran Gunungpati, Semarang, Indonesia \\ ${ }^{3}$ Pendidikan Geografi, Fakultas Ilmu Sosial, Universitas Negeri Yogyakarta, Jl. Colombo No.1 \\ Karangmalang, Yogyakarta, Indonesia
}

Correspondence: Nasir Nayan (email: nasir@fsk.upsi.edu.my)

Received: 13 November 2019; Accepted: 25 February 2020; Published: 27 February 2020

\begin{abstract}
Abstrak
Pengajaran dan pembelajaran pada zaman kini telah menjadikan penggunaan alat bantu mengajar yang lebih moden digunakan bagi menjadikan ia lebih disenangi dan diterima oleh generasi Z. Antara yang menjadi keperluan adalah telefon pintar dengan kebanyakan daripadanya menggunakan sistem operasi android. Artikel ini menerangkan proses pembinaan aplikasi android GeoSudut guru-pensyarah untuk subjek geografi di sekolah dan di peringkat sarjana muda di universiti. Artikel ini cuba untuk meneliti bagaimana satu aplikasi berasaskan android dapat dibangunkan untuk menyokong proses pengajaran dan pembelajaran kursus geografi dengan memberi fokus kepada pengiraan sudut bearing. Metodologi pendekatan penerokaan dipilih dalam menjelaskan proses membina aplikasi android GeoSudut. Tiga peringkat dilalui dalam kajian ini iaitu (i) analisis dokumenkeperluan membina aplikasi android, (ii) membangunkan perisian berasaskan waterfall model dan (iii) pengujian aplikasi android GeoSudut. Walau bagaimanapun untuk artikel ini peringkat ketiga tidak akan di ambil kira. Fokus pada aspek membangunkan perisian adalah pengiraan sudut yang sepenuhnya menggunakan android studio yang mengintegrasikan penggunaan kamera hadapan dan pengiraan secara on the fly yang melibatkan penggunaan bahasa pengaturcaraan bagi android. Dapatan kajian menunjukkan aplikasi android GeoSudut boleh digunakan untuk membantu dalam proses pengajaran dan pembelajaran. Kesimpulannya, pembangunan aplikasi berasaskan kepada telefon pintar perlu diperbanyakan lagi dan aplikasi GeoSudut ini boleh dikembangkan lagi dengan memasukkan aplikasi berkaitan pengajaran geografi bagi menangani generasi $\mathrm{Z}$ yang lebih suka kepada teknologi. Implikasinya adalah banyak lagi penyelidikan untuk membangunkan aplikasi-aplikasi yang berteraskan android perlu dilakukan untuk menjadikan sesi pengajaran dan pembelajaran lebih aktif bagi generasi $\mathrm{Z}$.
\end{abstract}

Kata kunci: alat bantuan mengajar, education 4.0, geografi, generasi Z, IR4.0, pembelajaran dan pemudahcaraan, telefon pintar android 


\title{
Android development in supporting Geography teaching and learning: A case study of GeoSudut
}

\begin{abstract}
The teaching and learning environment in the new millennium has tremendously employed modern teaching aid to generate interest and acceptance by the $\mathrm{Z}$ generation. Among others is the need for a smartphone that is dominated by android operating systems. This article describes the process of building an android application for geography subjects at school and university's bachelor degree level. This research seeks to explore how an android-based application can be developed to support the teaching and learning process of geography courses by focusing on the calculation of bearings. The exploration approach methodology was chosen in explaining the process of building a GeoSudut android. Three stages involved in this study are (i) analysis of android building requirements documents, (ii) construction of waterfall model-based software and (iii) android application testing. However this article will not cover the third objective. The development of the android application fully utilizes the android studio which integrates the use of front-facing cameras and computations algorithms involving the android programming language. The findings show that geo-android can be used to aid in teaching and learning. In conclusion, smartphone-based development applications need to be further developed and GeoSudut applications can be further expanded by incorporating geographically-based applications to address the Z-generation that prefers the use of technology. As for the implication, more research need to be carry out to develop an android-based application for teaching and learning for the $\mathrm{Z}$ generation.
\end{abstract}

Keywords: teaching aids, Education 4.0, geography, $\mathrm{Z}$ generation, IR4.0, teaching and learning, android smartphone

\section{Pengenalan}

Sistem pendidikan di seluruh dunia telah mengalami perubahan yang pesat dan sebahagian besar disebabkan oleh kemajuan dalam teknologi yang memberi ruang dan mencipta peluang besar terhadap perubahan dalam pendidikan (Kerski, Demirci \& Andrew, 2013). Penggunaan teknologi dalam pendidikan yang semakin meluas di peringkat global menekan guru dan pelajar untuk melengkapkan diri dengan pengetahuan dan kemahiran yang berkaitan dengan ruang lingkup teknologi yang memberi kesan yang besar terhadap kehidupan masa kini di Malaysia (Siti Aminah \& Fazlinda, 2018). Dalam konteks Malaysia, ianya selaras dengan Pelan Pembangunan Pendidikan Malaysia (PPPM) 2015-2025, iaitu Kementerian Pendidikan Malaysia memfokuskan kepada keberhasilan, berbanding input, disamping menggunakan teknologi dan inovasi bagi memenuhi keperluan serta meningkatkan pengalaman pembelajaran pelajar. Dinyatakan juga dalam PPPM 2015-2025 bahawa hasrat negara adalah untuk menjadi hub pendidikan berkualiti dan pelajar akan berpeluang mengikuti program yang lebih berkualiti dan berteraskan model pembelajaran berasaskan pengalaman (experiential learning) dan pembelajaran berasaskan teknologi (technology-enabled learning) supaya lebih menarik dan mencabar (Kementerian Pendidikan Malaysia, 2015). Pendidikan di Malaysia juga telah memperkenalkan pelbagai Bahan Bantu Mengajar (BBM) sebagai media yang digunakan ketika pengajaran dan pembelajaran. Abad ke-21 dan abad seterusnya akan menyaksikan penggunaan kepelbagaian BBM dalam pendidikan dilihat semakin meluas dan banyak membantu para guru-pensyarah dan pelajar dalam menjalankan pembelajaran dan 
pemudahcaraan $(\mathrm{PdPc})$ dalam bilik darjah di sekolah dan juga sewaktu kuliah di peringkat universiti.

BBM bermaksud peralatan atau bahan yang digunakan oleh tenaga pengajar dan pelajar dalam proses pengajaran dan pembelajaran yang melibatkan peralatan atau bahan berinovasi seperti peralatan komputer, multimedia, perisian, kad imbasan, buku teks dan sebagainya bagi meningkatkan perasaan ingin tahu pelajar terhadap sesuatu mata pelajaran yang diajar oleh guru dan akan lebih fokus untuk belajar (Faizah, 2017). Dalam konteks pendidikan, BBM multimedia adalah seperti alat komputer, buku, projektor slaid, unjuran video, projektor overhead, kamera dokumen, sistem audio (pemain $\mathrm{CD}$, radio), sistem bunyi dan video gabungan (televisyen, kamera video digital dan DVD) yang bertujuan untuk membuat, menyimpan dan menyampaikan kandungan pengajaran (De Sousa et al., 2017). BBM juga boleh melibatkan sistem operasi android yang boleh dimasukkan ke dalam kebanyakan daripada telefon pintar masa kini. Berdasarkan kepada Revolusi Industri 4.0, penggunaan alat berteknologi masih boleh digunakan untuk membantu dalam pendidikan seperti android ini. Bantuan alat seperti ini sudah semestinya akan membantu dalam ilmu pengetahuan itu dengan mempercepatkan proses pemahaman. Artikel ini bertujuan untuk menerangkan reka bentuk yang boleh digunakan dalam membina prototaip alat bantu mengajar menggunakan android yang boleh digunakan semua orang termasuklah pelajar universiti yang mengambil mata pelajaran geografi, guru, pelajar sekolah dan ibu bapa. Pembinaan sistem ini juga selari dengan Pelan Pembangunan Pendidikan Malaysia (PPPM) dengan menjurus kepada lonjakan Innovation Ecosystem serta Revolusi Industri 4.0. Dalam kajian ini satu pembinaan aplikasi dibina bertujuan memenuhi keperluan pelajar universiti khususnya pelajar Ijazah Sarjana muda Pendidikan (Geografi) dengan Kepujian di UPSI perlu menguasai teknik ini dalam kursus HGR3013 Teknik-teknik dan Kuantitatif dalam Geografi dan perlu digunakan kemahiran ini semasa pelajar mengambil kursus KPR3028 Latihan Mengajar. Sama juga keadaannya bagi pengajaran geografi menengah rendah iaitu tingkatan 1, 2 dan 3 yang memerlukan pemahaman pengukuran sudut bearing. Ia juga digunakan untuk tingkatan menengah atas untuk bahagian kemahiran peta dan juga semasa mengambil STPM. Pada masa kini bagi mengira sudut bearing dalam mata pelajaran masih menggunakan alat manual dan agak sukar untuk guru mengajar penggunaan alat tersebut untuk setiap orang pelajarnya.

Matlamat utama kajian ini adalah untuk mendedahkan bagaimana aplikasi berasaskan android untuk PdPc boleh dibina. Malahan, penyelidikan ini dibataskan kepada hanya item pengiraan sudut sahaja, menerusi pengguna sistem operasi android dan telefon pintar yang mempunyai kamera hadapan sahaja. Telefon pintar pula dikhususkan kepada sistem operasi android sahaja yang mempunyai liputan penggunaan yang tinggi dalam kalangan masyarakat. Ini disebabkan harga telefon pintar yang mengandungi sistem operasi android adalah berpatutan dan masyarakat pelajar IPTA masih mampu untuk membelinya. Tambahan penggunaan telefon pintar adalah tidak asing lagi dalam kalangan pelajar IPTA dan ini termasuklah juga di UPSI. Pada masa ini pakej aplikasi android (android application package -APK) diletakkan dalam Google Drive dan disebarkan kepada pelajar melalui cara muat turun. APK ini tidak diletakkan lagi di dalam Google Play.

\section{Kajian literatur}

Terdapat pelbagai jenis BBM yang boleh dikenal pasti. BBM terdiri dari alat bantu mengajar yang asas seperti buku kerja, gambar, peta, carta, dan yang seumpamanya serta alat bantu mengajar elektronik seperti jalur filem, wayang gambar, televisyen, radio, gramotor dan video, dan malahan ada yang menyatakan bahawa BBM terdiri daripada papan hitam, buku 
bercetak, alat pandang dengar dan alat ciptaan baharu seperti alat-alat multimedia. BBM bukan elektronik adalah seperti papan hitam atau papan tulis, buku teks, papan pamer atau papan buletin, fail tegak dan bahan bacaan, gambar, kad imbasan dan kad cantuman, carta, grafik, papan pengajaran, model tiga dimensi, boneka atau patung dan diorama. Manakala BBM elektronik adalah seperti Overhead Projektor (OHP), transparensi OHP, pita slaid (filem slaid), radio, televisyen dan VCR (Video Cassette Recorder), alat rakaman, filem tayang atau filem jalur, komputer dan kini penggunaan telefon pintar dengan aplikasi yang menggunakan platform android.

Alat bantu mengajar (ABM) atau pun bahan bantu mengajar (BBM) adalah merupakan segala alatan yang digunakan guru/murid untuk membantu penyampaian pengajaran di bilik darjah (Brown, 1983). BBM tidak terhad hanya buku teks, papan tulis, kapur, dan gambar-gambar sahaja, tetapi ia merangkumi semua bahan yang digunakan dalam pengajaran dan pembelajaran dan melibatkan semua pancaindera dan apa sahaja yang dapat dialami oleh para pelajar. Sivakumar (2015) juga memperakukan bahawa keperluan kepada penggunaan teknologi seperti android ini dalam mempertingkatkan penguasaan pelajar universiti khususnya dalam penguasaan berbahasa Inggeris. Walker (2011) pula menjelaskan penggunaan teknologi seperti android ini dapat mempertingkatkan penguasaan beberapa subjek dalam statistik bagi pelajar tahun pertama di Swinburne University of Technology. Johnson et al. (2012), mengatakan seiring dengan pembangunan teknologi dunia, dunia pengajaran dan pembelajaran di universiti juga perlu bergerak ke arah selari dengan penggunaan teknologi seperti android. Ini dikukuhkan lagi oleh Hsu dan Ching (2012) yang memperkatakan tentang penggunaan telefon bergerak dalam peningkatan pengetahuan. Inovasi dalam aplikasi bergerak ini secara langsung telah menarik minat pendidik untuk menggunakannya setanding dengan kewujudan bahan seperti telefon pintar di dunia.

Tidak banyak BBM yang dibina berasaskan kepada android pada masa sekarang dan yang ada antaranya seperti aplikasi Jamak Qasar Apss (Nurkaliza et al., 2015) yang dibina bagi memudahkan pengguna untuk mempelajari kaedah untuk melaksanakan solat jamak dan qasar. Sedangkan aplikasi android yang berkaitan dengan sub tema yang ada dalam mata pelajaran geografi seperti pengiraan arah bearing, sudut, kecerunan dan sebagainya telah mula diwujudkan dan sebagai contohnya aplikasi protractor yang mengira sudut, multi clinometer yang mengira sudut dalam darjah dan peratusan, malahan interaktif dengan peta pun sudah ada. Jadi keperluan untuk membina sebuah prototaip yang dikhususkan untuk keseluruhan kursus dan mata pelajaran geografi di IPTA dan sekolah amat diperlukan selari dengan teknologi dan kaedah PdPc sekarang.

Revolusi Industri 4.0 (IR4.0) adalah situasi perubahan berkaitan teknologi dalam pelbagai zaman (Anealka, 2018). Permulaan revolusi perindustrian memungkinkan kewujudan alatan untuk membantu manusia dalam pekerjaan. Secara tidak langsung keperluan kepada kemahiran ini juga termasuk dalam pendidikan semasa itu. Keadaan yang sama juga terjadi dengan kewujudan IR4.0 yang mana keperluan kepada pengetahuan manusia yang terjalin dengan kewujudan elemen digital dan internet untuk membantu manusia. Kewujudan IR4.0 ini seterusnya memberikan impak kepada pendidikan dengan kemasukan elemen teknologi di peringkat seawal di peringkat pra sekolah lagi. Murid diperkenalkan dengan penggunaan BBM untuk membantu mereka dalam PdPc (Aida Aryani \& Norhayati, 2018).

Asasnya, artikel ini akan menerangkan tentang reka bentuk untuk membina satu prototaip alat bantu mengajar yang digunakan oleh pensyarah dan pelajar semester 1, Ijazah Sarjanamuda Pendidikan (Geografi) bagi pelajar major dan Semester 3 bagi pelajar minor Geografi. Teknik pembelajaran abad ke-21 (PAK21) yang telah dimulakan sejak tahun 2014, mengutarakan penekanan kepada pemusatan pembelajaran murid dengan menekankan elemen komunikasi, kolaboratif, pemikiran kritis, kreativiti dan aplikasi nilai murni yang 
dikenali sebagai standard asas PAK21. Elemen-elemen ini boleh dihubungkan dengan prototaip ini apabila aktiviti yang berlangsung sama ada dalam bilik darjah atau luar kelas berbantukan dengan prototaip ini yang boleh diakses di mana juga. Alat-alat bantu mengajar seperti ini secara langsung akan menyemarakkan lagi minat pelajar kepada teknologi yang seterusnya menjurus mereka kepada jurusan sains teknologi kejuruteraan dan matematik (STEM). Kemahiran penggunaan teknologi dijangka akan membantu pelajar UPSI untuk lebih menguasai teknologi dan dapat menjalankan PdPc program perantis guru (PPG) dan latihan mengajar mereka.

Idealnya, semua pelajar peringkat Sarjanamuda Pendidikan (Geografi) dengan Kepujian serta pelajar yang mengambil minor Geografi mempunyai asas dalam kemahiran geografi. Mereka telah didedahkan dengan kemahiran ini dalam kursus HGR3013 Teknikteknik dan Kaedah Kuantitatif dalam Geografi. Pelajar ini sememangnya didedahkan dengan penggunaan alatan tradisional seperti jangka sudut bearing. Ini menjadikan PdPc semasa kuliah kurang menarik dengan kurangnya elemen teknologi terkini seperti penggunaan telefon pintar dan juga android. Malahan, terdapat juga komen-komen negatif daripada guru pembimbing di sekolah yang menyatakan bahawa kurangnya kemahiran pelajar UPSI semasa berlangsungnya kursus KPR3028 Latihan Mengajar. Bagi meningkatkan kemahiran dan minat pelajar maka cadangan dikemukakan untuk membina BBM yang bercirikan Android yang membolehkan latihan dan pemahaman kepada pelajar HGR3013 dan juga kepada pelajar KPR3028 nanti.

Pendedahan kemahiran geografi adalah salah satu elemen yang penting dalam pemetaan yang diletakkan dalam mata pelajaran geografi seperti dan sub tema dalam elemen ini melibatkan pengetahuan arah mata angin dan kedudukan koordinat. Bagi sub tema arah pula ia merujuk terus kepada arah mata angin dan bearing sudutan serta bearing arah. Pada masa kini pelajar UPSI dan pensyarah menggunakan jangka sudut untuk mendapatkan sudutan yang diperlukan. Isu permasalahan yang ingin diketengahkan adalah kemahiran dan pengetahuan pelajar UPSI yang masih rendah dalam Kemahiran Geografi yang diperlukan dalam kursus HGR3013 dan diajar kembali semasa KPR3028. Amriah (2007) memberitahu keperluan kepada kemahiran praktikal Geografi di peringkat IPTA diperlukan untuk membolehkan masalah fundamental diselesaikan. Malahan Abdul Samad (2013) juga menyatakan keperluan kepada kemahiran khusus yang diperlukan untuk memberikan sumbangan lebih bermakna. Shamsiah (2012) menyatakan keperluan kepada kemahiran teknologi merupakan keperluan perlu ada kepada pelajar universiti. Keperluan BBM seperti ini selaras dengan PAK21 yang menitikberatkan kepada keupayaan pelajar untuk berfikir secara kritikal membolehkan penggunaan BBM yang baharu seperti pengiraan sudut ini dengan menggunakan gajet telefon pintar yang telah digunakan secara meluas. Penggunaan aplikasi ini membantu untuk melancarkan lagi pemahaman pelajar dan menarik minat pelajar untuk mengikuti pembelajaran menggunakan sains, teknologi dan kejuruteraan. Pada masa kini tidak ada lagi BBM yang dibuat untuk membantu PdP berasaskan kepada android terutamanya untuk elemen kemahiran geografi.

\section{Metodologi}

Artikel ini menggunakan pendekatan penerokaan dengan membina prototaip aplikasi. Walau bagaimanapun, sebelum prototaip dibangunkan beberapa peringkat perlu dibuat iaitu (i) analisis dokumen-keperluan membina android yang melibatkan penelitian dokumen peringkat sekolah iaitu Dokumen Standard Kurikulum dan Pentaksiran (DSKP) bagi tingkatan 1 hingga 5 serta Proforma bagi kursus HGR3013, (ii) membangunan perisian berasaskan waterfall model dan (iii) pengujian android GeoSudut. Analisis dokumen adalah analisis keperluan 
untuk membina android GeoSudut. Analisis akan melibatkan dokumen proforma bagi kursus HGR3013 untuk meneliti keperluan-keperluan dalam pembangunan. Bagi analisis dokumen untuk DSKP dan Proforma, penelitian dibuat untuk menentukan tema kemahiran geografi yang digunakan di sekolah dan UPSI. Dokumen Proforma kursus HGR3013 Teknik-teknik Kartografi dalam Geografi dengan melihat kepada tema-tema berkaitan kemahiran geografi dengan berfokuskan kepada pengukuran arah, bearing dan kecerunan.

Seterusnya pada fasa kedua akan melibatkan pembangunan perisian berasaskan waterfall model (Darwin, 2016) seperti dalam rajah 1. Model ini menggunakan pendekatan sistematik yang menekankan kepada turutan pembangunan yang dimulai dengan penilaian keperluan (requirement study) yang melibatkan kepada analisis dokumen yang merujuk terus kepada kemahiran geografi yang ada dalam Proforma, Rancangan Kursus HGR3013 TeknikTeknik dan Kaedah Kuantitatif dalam Geografi bagi keperluan untuk membina prototaip aplikasi. Seterusnya adalah peringkat pengaturcaraan untuk merealisasikan reka bentuk dengan menggunakan bahasa pengaturcaraan seperti J2ME berdasarkan kepada reka bentuk aplikasi android yang akan dibina. Pada masa ini juga data kedudukan $\mathrm{x}$ dan y bagi menentukan paksi $\mathrm{X}$ dan $\mathrm{Y}$ akan ditentukan melalui penggunaan kamera di telefon pintar dan seterusnya pengiraan akan dibuat berdasarkan kepada kedudukan itu. Maklumat itu akan disimpan dalam telefon pintar dan diguna semula dalam aplikasi menggunakan koding pengaturcaraan. Seterusnya beta testing akan dilakukan dengan menggunakan muat turun daripada Google Drive yang mana pengguna akan memuat turun aplikasi dan memberikan pandangan melalui Google Doc atau emel. Pandangan dan glitch akan disesuaikan semula melalui pembaikan dalam pengaturcaraan seperti dalam rajah 2. Platform android adalah pakej perisian yang digunakan untuk membangunkan aplikasi berasaskan alatan mobil. Pengguna akan menggunakan antara muka ini untuk memilih apa yang dikehendaki dan menghantar semula kepada aplikasi yang akan memproses permintaan ini secara di belakang dan seterusnya akan dihantar kembali kepada pengguna melalui paparan kembali. Pada masa yang sama keseluruhan reka bentuk aplikasi boleh diterjemahkan seperti dalam rajah 3. Datadata yang digunakan melibatkan penggunaan data peta sedia ada yang dibekalkan oleh Google seperti dalam Google maps dan dengan penggunaan antara muka aplikasi pengaturcaraan (application programming interface - API) yang boleh dimuat turun untuk digunakan.

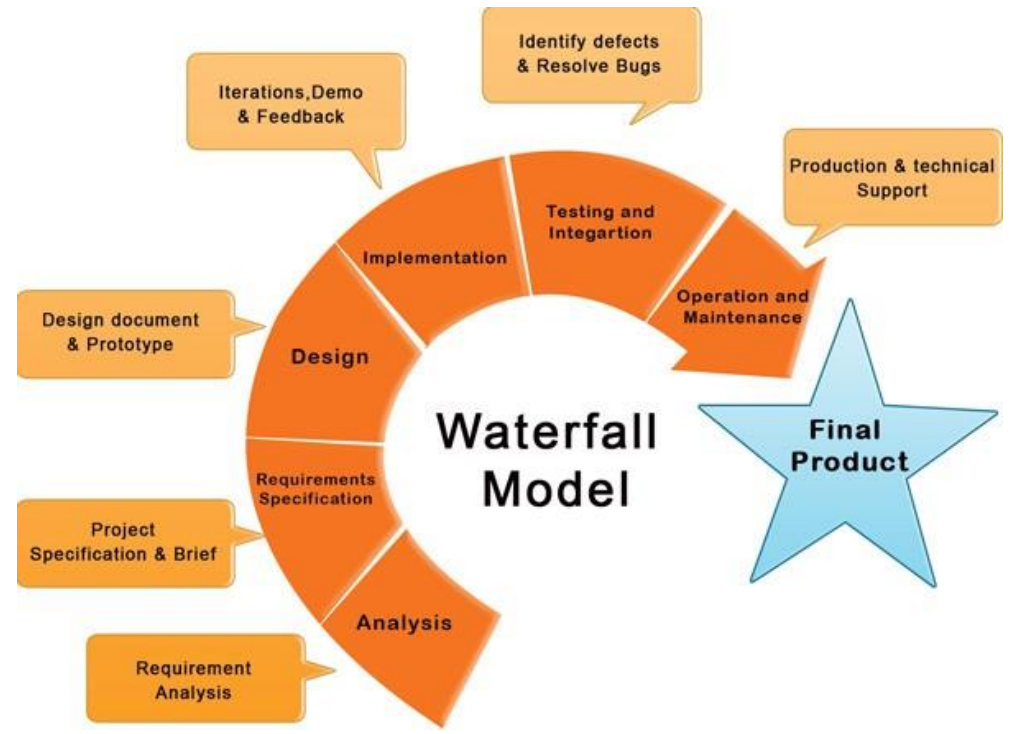

Sumber: Darwin (2016)

Rajah 1. Langkah dalam pembangunan aplikasi berdasarkan Model Waterfall 


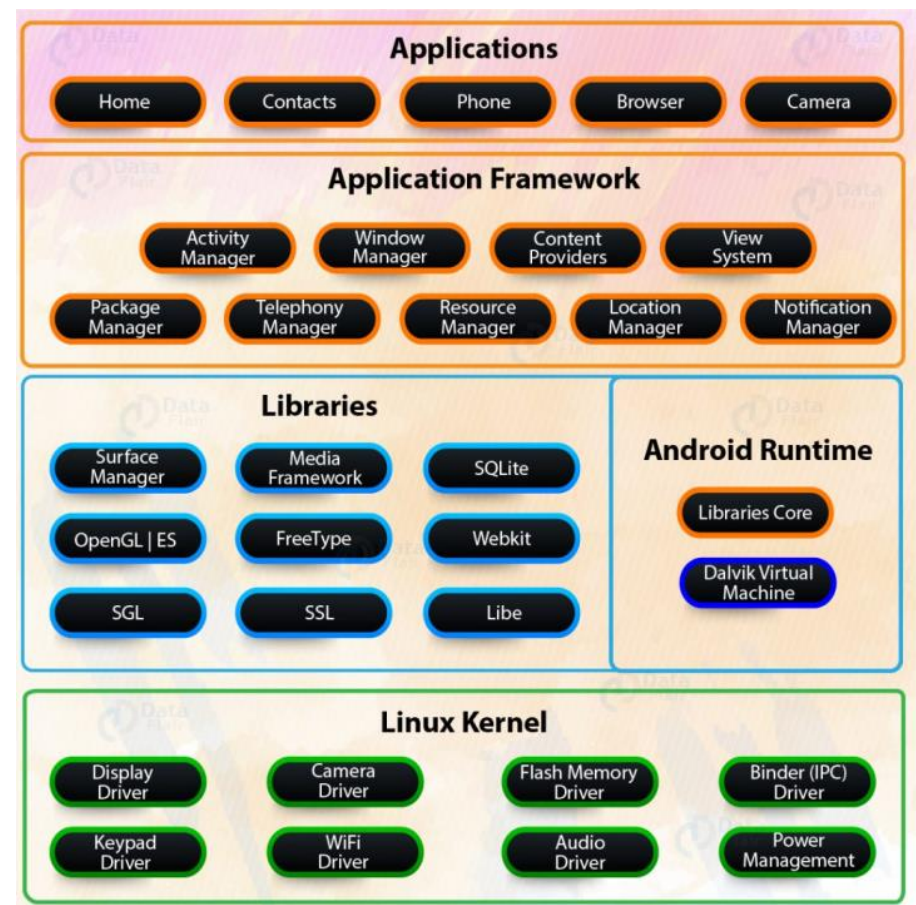

Sumber: Ubahsuai dari Sharma (2019)

Rajah 2. Keseluruhan reka bentuk berasaskan android

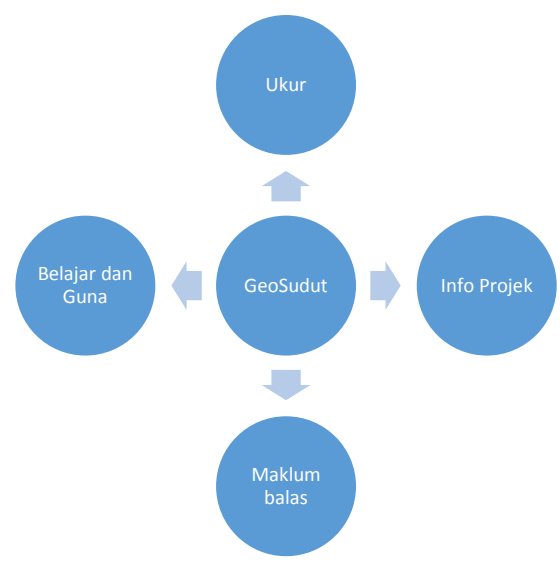

Rajah 3. Antara muka utama dalam reka bentuk GeoSudut

\section{Hasilan dan perbincangan}

\section{Analisis dokumen standard kurikulum pembelajaran dan proforma}

DSKP adalah sebahagian daripada Kurikulum Standard Sekolah Menengah (KSSM) yang menggantikan Kurikulum Bersepadu Sekolah Menengah (KBSM) yang bermula secara berperingkat dari tingkatan 1 bermula pada tahun 2017. DSKP dirangka untuk mengantarabangsakan pendidikan di sekolah menengah seperti yang di amalkan di peringkat antarabangsa dengan memasukkan standard kandungan, standard pembelajaran dan standard pentaksiran. Pada masa yang sama elemen kemahiran selain daripada pengetahuan, nilai, kemahiran Abad ke-21, Kemahiran Berfikir Aras Tinggi (KBAT) yang diintegrasikan bersama. 
Terdapat lima (5) kandungan kurikulum dalam KSSM iaitu Kemahiran Geografi, Geografi Fizikal, Geografi Manusia, Geografi Kawasan serta Isu dan Pengurusan Alam Sekitar. Strategi pengajaran dan pembelajaran dalam kurikulum Geografi menekankan kepada pendekatan berpusatkan murid. Pendekatan berpusatkan murid menjadikan mata pelajaran ini lebih menyeronokkan terutamanya apabila murid diberi peluang untuk mengemukakan pendapat tentang sesuatu isu atau tajuk yang dipelajari berkaitan geografi. Rajah 4, menunjukkan bagaimana kandungan yang ada dalam KSSM dan keperluan setiap kandungan untuk penerapan pengetahuan, kemahiran dan nilai untuk murid.

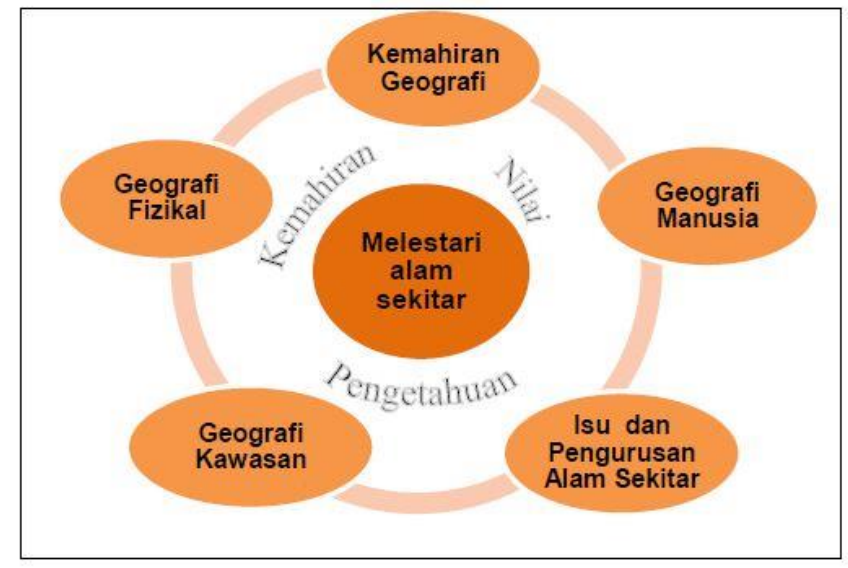

Sumber: Kementerian Pendidikan Malaysia (2015)

Rajah 4. Integrasi kandungan KSSM dan Elemen

Bagi elemen Kemahiran Geografi merangkumi kemahiran memerhati, mengukur, merekod, menyampaikan maklumat, membina jadual dan graf, melakar peta serta mentafsir jadual, graf dan peta. Kemahiran ini dipelajari melalui tajuk arah, kedudukan, peta, skala dan jarak, jadual, graf, dan carta. Tajuk-tajuk dalam Kemahiran Geografi membolehkan murid mengkaji dan menghubungkaitkannya dalam organisasi ruang. Kemahiran Geografi memberi tumpuan kepada pemerolehan kemahiran menggunakan kompas, alat ukur, atlas dan glob. Walau bagaimanapun bagi KSSM untuk tingkatan 4 dan 5, terdapat perbezaan dengan berfokuskan kepada pelestarian alam sekitar dengan melibatkan tiga (3) standard iaitu Kemahiran Geografi, Geografi Fizikal dan Geografi Manusia dengan masih menekankan elemen yang sama iaitu pengetahuan, kemahiran dan nilai. Integrasinya adalah seperti dalam rajah 5.

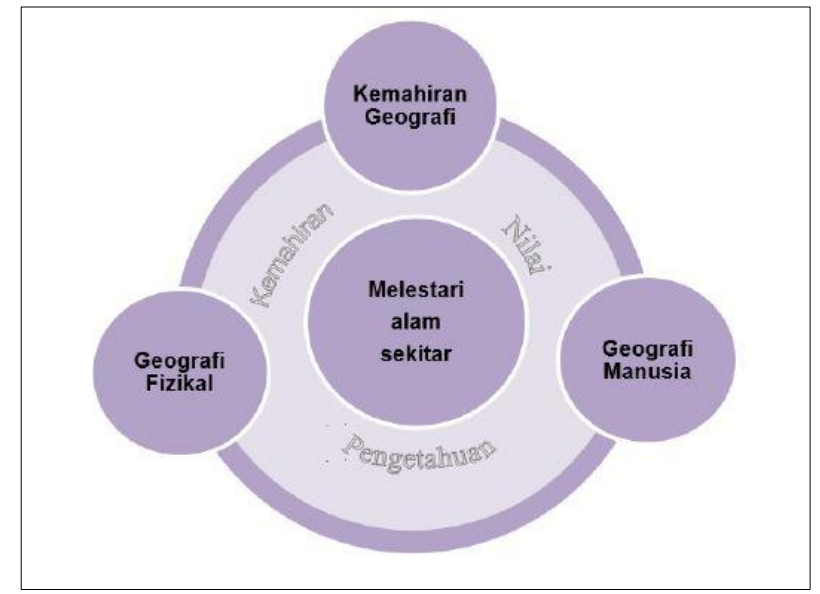

Sumber: Kementerian Pendidikan Malaysia (2018)

Rajah 5. Integrasi kandungan KSSM Tingkatan 4 dan 5 berbanding Elemen 
Jadual 1 adalah ringkasan kepada analisis dokumen yang melibatkan enam dokumen yang digunakan dalam menentu keperluan kemahiran geografi dalam pelbagai peringkat. Asasnya UPSI melalui kursus HGR3013 Teknik-teknik Kartografi dalam Geografi telah menyediakan asas untuk bakal guru dengan sekurang-kurangnya 3 jam pembelajaran kuliah dan tugasan. Pada masa yang sama keperluan untuk kemahiran geografi bagi pengukuran bearing dan sudut juga terdapat di sekolah iaitu pada peringkat sekolah menengah rendah dan sekolah menengah atas. Bagi sekolah menengah rendah yang melibatkan tiga tingkatan iaitu tingkatan 1, 2 dan 3, hanya pada tingkatan 3 sahaja kemahiran geografi untuk pengukuran bearing sudutan dijalankan. Malahan standard yang digunakan juga hanya melibatkan penggunaan jangka sudut sahaja. Seiringan dengan IR4.0 yang melibatkan penggunaan alatan. Kesimpulannya untuk memahami sudut dalam PdPc geografi, bahan berbantukan telefon pintar seperti GeoSudut juga boleh digunakan.

Jadual 1. Analisis dokumen untuk kemahiran geografi

\begin{tabular}{|c|c|c|c|c|c|}
\hline Dokumen & Nama & Peringkat & $\begin{array}{l}\text { Standard } \\
\text { Kandungan/ } \\
\text { Bab/ Minggu } \\
\end{array}$ & Tajuk/Tema & $\begin{array}{l}\text { Sub tajuk/sub } \\
\text { tema }\end{array}$ \\
\hline DSKP & $\begin{array}{l}\text { DSKP } \\
\text { Tingkatan } 1\end{array}$ & $\begin{array}{l}\text { Sekolah } \\
\text { Menengah } \\
\text { Rendah }\end{array}$ & $\begin{array}{l}\text { Kemahiran } \\
\text { Geografi - Arah }\end{array}$ & $\begin{array}{l}\text { Arah mata angin } \\
\text { dan bearing } \\
\text { sudutan. }\end{array}$ & $\begin{array}{l}\text { Mengukur bearing } \\
\text { sudutan pada peta } \\
\text { dengan } \\
\text { menggunakan } \\
\text { jangka sudut. }\end{array}$ \\
\hline DSKP & $\begin{array}{l}\text { DSKP } \\
\text { Tingkatan } 2\end{array}$ & $\begin{array}{l}\text { Sekolah } \\
\text { Menengah } \\
\text { Rendah }\end{array}$ & & $\begin{array}{l}\text { Tiada berkaitan } \\
\text { tentan bearing } \\
\text { sudutan }\end{array}$ & \\
\hline DSKP & $\begin{array}{l}\text { DSKP } \\
\text { Tingkatan } 3\end{array}$ & $\begin{array}{l}\text { Sekolah } \\
\text { Menengah } \\
\text { Rendah }\end{array}$ & & $\begin{array}{l}\text { Tiada berkaitan } \\
\text { tentan bearing } \\
\text { sudutan }\end{array}$ & \\
\hline DSKP & $\begin{array}{l}\text { DSKP } \\
\text { Tingkatan } 4\end{array}$ & $\begin{array}{l}\text { Sekolah } \\
\text { Menengah } \\
\text { Atas }\end{array}$ & $\begin{array}{l}\text { Kemahiran } \\
\text { Geografi - Arah } \\
\text { dan Kedudukan } \\
\text { dalam Peta } \\
\text { Topografi }\end{array}$ & $\begin{array}{l}\text { Mengukur bearing } \\
\text { grid sesuatu lokasi } \\
\text { dalam peta } \\
\text { topografi. }\end{array}$ & $\begin{array}{l}\text { Memilih arah dan } \\
\text { kedudukan } \\
\text { sesuatu lokasi } \\
\text { untuk menentukan } \\
\text { bearing grid } \\
\text { dalam peta } \\
\text { topografi. }\end{array}$ \\
\hline DSKP & $\begin{array}{l}\text { DSKP } \\
\text { Tingkatan } 5\end{array}$ & $\begin{array}{l}\text { Sekolah } \\
\text { Menengah } \\
\text { Atas }\end{array}$ & & $\begin{array}{l}\text { Tiada berkaitan } \\
\text { tentan bearing } \\
\text { sudutan }\end{array}$ & \\
\hline Proforma & $\begin{array}{l}\text { Proforma } \\
\text { HGR3013 } \\
\text { Teknik-teknik } \\
\text { Kartografi } \\
\text { dalam } \\
\text { Geografi }\end{array}$ & UPSI & 10 & $\begin{array}{l}\text { Arah, bearing, } \\
\text { kecerunan dan } \\
\text { perletakan }\end{array}$ & $\begin{array}{l}\text { - Penentuan arah } \\
\text { dan bearing } \\
\text { - Pengiraan } \\
\text { kecerunan } \\
\text { - Penentuan } \\
\text { perletakan }\end{array}$ \\
\hline
\end{tabular}

\section{Pembinaan aplikasi android GeoSudut}

Aplikasi GeoSudut ini dibina menggunakan pengaturcaraan berasaskan kepada android dengan berbantukan kepada perisian Android Studio. Rajah 3 menunjukkan butang-butang fungsi dalam GeoSudut. Main frame dibina berasaskan kepada pengaturcaraan android dengan menambah beberapa butang iaitu butang utama ukur, info projek, belajar dan guna serta butang maklum balas. Apabila butang ditekan maka pengguna akan dibawa ke fungsi aplikasi yang diperlukan. Fungsi utama dalam aplikasi ini adalah pada butang UKUR yang membawa pengguna kepada penggunaan kamera hadapan yang telah dibina satu jangka 
sudut. Pengunaan kamera dan skrin sesentuh yang dibina berasaskan kepada android membolehkan aplikasi ini berfungsi. Fungsi-fungsi lain pula adalah menggunakan standard HTML yang di bina dalam android studio seperti untuk butang info serta belajar dan guna. Tetapi bagi butang maklum balas, penggunaan Google Drive yang dibina borang soal selidik bagi mendapatkan data daripada pengguna.

Antara muka GeoSudut ini terbahagi kepada beberapa bingkai (frame) yang dikenali dengan bingkai utama (main frame) dan bingkai-bingkai aplikasi lainnya iaitu bingkai untuk menggunakan aplikasi, bingkai penerangan berkaitan projek dan bingkai cara untuk menggunakannya serta bingkai maklum balas seperti Rajah 6a. Bingkai utama ini mengandungi selain daripada butang yang menghubungkan dengan bingkai lain dengan cara menekan butang yang dikehendaki seperti butang UKUR. Bingkai ini juga mengandungi logo tentang pemberi dana penyelidikan iaitu Universiti Pendidikan Sultan Idris, Pusat Pembangunan Akademik dan logo Fakulti Sains Kemanusiaan.

Pengguna perlu mendapatkan dahulu kawasan yang ingin di ukur sudut, sama ada dengan mendapatkan daripada sumber kedua atau melukis sendiri di atas kertas. Pengguna seterusnya boleh menggunakan aplikasi GeoSudut ini dengan menekan butang UKUR (rajah 6a) dan akan di bawa kepada bingkai yang mengandungi garisan pengukuran bersama dengan kamera yang dibuka (rajah 6b). Pengguna menetapkan paksi utara kepada kedudukan yang betul dan titik permulaan pertindihan atau 0 darjah di tempat sepatutnya (rajah 6b). Setelah berpuas hati, pengguna perlu menekan butang AMBIL GAMBAR untuk menetapkan kawasan pengukuran. Selepas itu pengguna menggunakan teknik psikomotor tangannya untuk menarik logo di garisan utara kepada titik yang dikehendaki dan aplikasi secara automatik akan membuat pengiraan secara on the fly (rajah 6c). Proses ini boleh diulangulang dengan hanya menekan butang BACK pada telefon pintar pengguna.

Rajah 6d dan 6e adalah bingkai yang ditunjukkan selepas pengguna menekan butang INFO PROJEK. Bingkai ini menunjukkan latar belakang projek penyelidikan yang dijalankan dan penyelidik yang terlibat serta cara untuk menghubungi mereka. Untuk kembali ke bingkai utama, pengguna perlu menekan butang BACK yang sedia ada dalam telefon mereka. Pengguna yang menekan butang BELAJAR DAN GUNA pada bingkai utama akan dibawa kepada bingkai seterusnya seperti dalam Rajah 6f hingga 61. Bergantung pada saiz paparan telefon pengguna, paparan maklumat berkaitan sudut dan cara menggunakan GeoSudut akan dipaparkan. Pengguna boleh menatal ke bawah (scroll down) dan ke atas (scroll up).

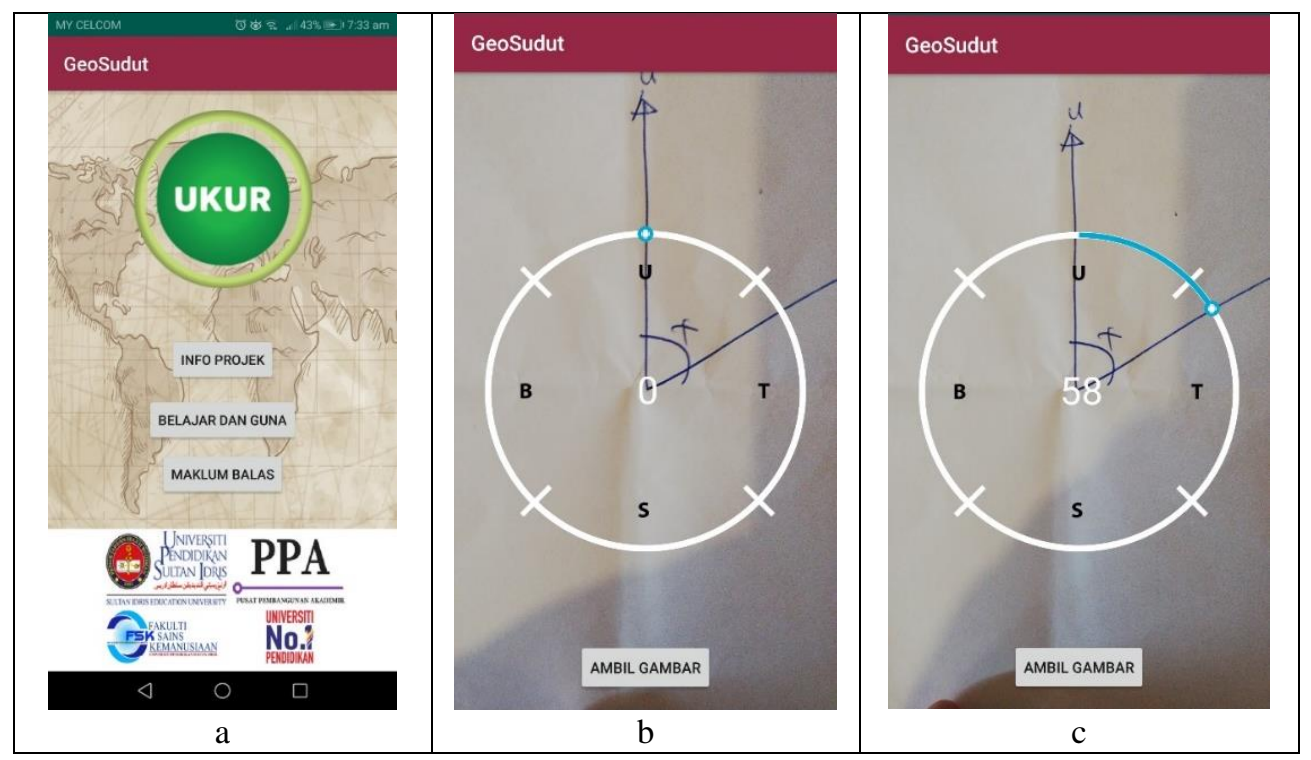




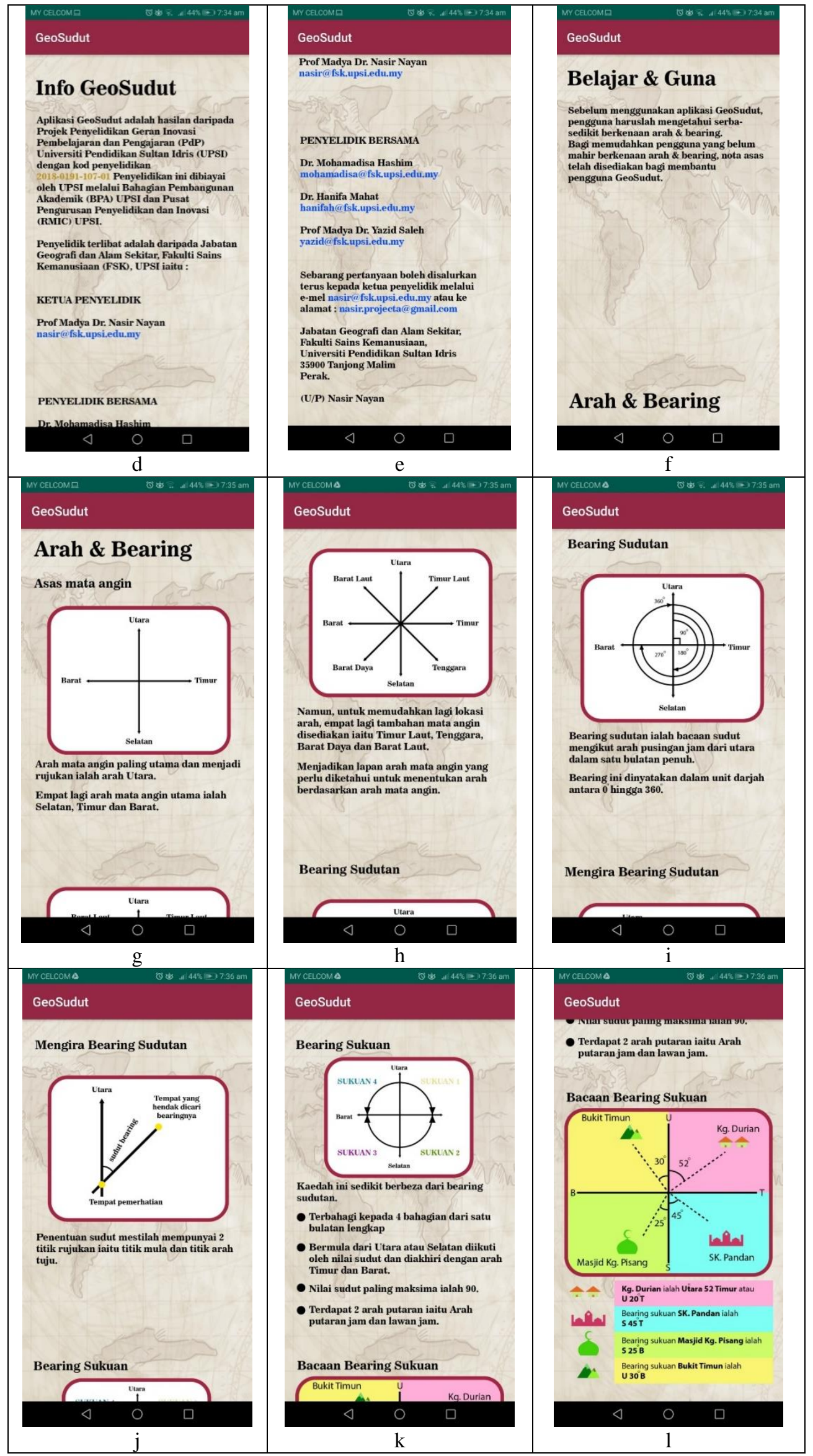




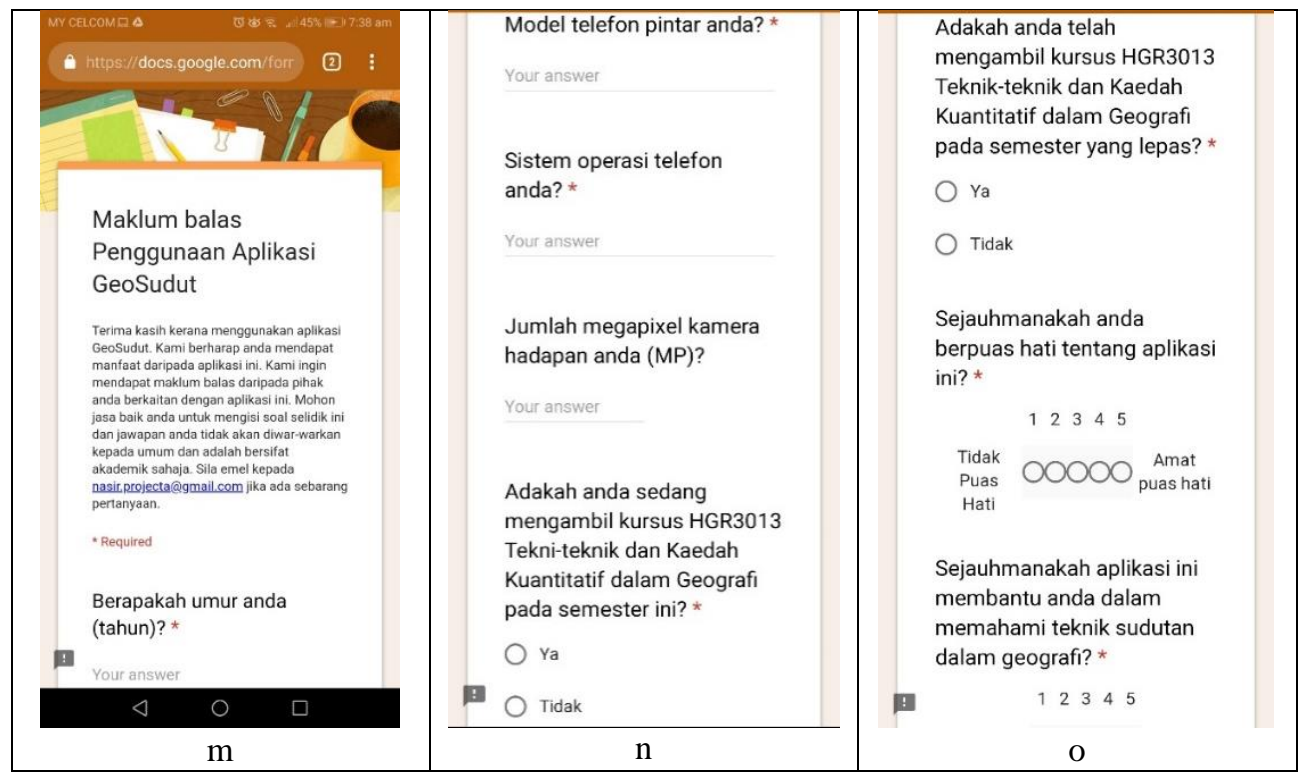

Rajah 6. Antara muka GeoSudut

\section{Kesimpulan}

Teknologi tercipta daripada kepintaran manusia bagi memudahkan kehidupan mereka. Sama juga dengan pembangunan GeoSudut ini yang cuba untuk membantu guru, pelajar univesiti, murid sekolah dan ibu bapa dalam memahami elemen pengukuran sudut dalam PdPc geografi. Kandungan pengajaran dalam DSKP mata pelajaran geografi di sekolah tidak berubah. Cuma bagaimanakah PdPc boleh dijalankan untuk memudahkan pemahaman murid terhadap elemen pengukuran sudut ini. Cuma situasi bagaimana kandungan itu disampaikan mungkin berbeza-beza mengikut kaedah semasa. Masa kini, teknologi android dalam telefon pintar adalah salah satu daripada yang terkini. Pembangunan aplikasi GeoSudut ini adalah sejajar dengan keperluan semasa bagi menerangkan isi kandungan kepada Generasi $\mathrm{Z}$ yang memerlukan rangsangan berbentuk teknologi dalam pengajaran. GeoSudut ini boleh lagi dinaik taraf untuk digunakan bagi guru dan murid di sekolah di peringkat menengah rendah Malaysia.

\section{Penghargaan}

Terima kasih kepada Universiti Pendidikan Sultan Idris melalui Pusat Pengurusan Penyelidikan dan Inovasi (RMIC) bersama Bahagian Pembangunan Akademik yang menyediakan dana Geran Inovasi Pengajaran dan Pembelajaran (PdP) (kod penyelidikan: 2018-0191-107-01 yang bertajuk Pembinaan Alat Bantu Mengajar bagi Elemen Kemahiran Geografi Menggunakan Android) bagi menjalankan penyelidikan berkaitan dengan artikel kerja ini.

\section{Rujukan}

Abdul Samad Hadi. (2013). Menyusuri Kembali 'The Nature of Geography': Membina Kerelevanan Baru Menerusi Transdisiplinari. PERSPEKTIF 4(1): 126-144. 
Aida Aryani Shahroom, \& Norhayati Hussin. (2018). Industrial Revolution 4.0 and education. International Journal Academic Research in Business \& Social Sciences. 8(9): 314-319.

Amriah Buang. (2007). Memperkasa Geografi Manusia di Malaysia: Isu dan Cabaran. Jurnal e-Bangi 2(2): 1-23.

Anealka Aziz Hussin. (2018). Education 4.0 made simple: Ideas for teaching. International Journal of Education \& Literacy Studies. 6(3): 92-98.

Atan Long (1982). Psikologi pendidikan. Dewan Bahasa dan Pustaka, Kuala Lumpur.

Brown J.W. (1983). Perceived environmental uncertainty and the two-step flow process of scientific and technical communication in research and development laboratories. $\mathrm{Ph} . \mathrm{D}$, Indiana University, Bloomington, Indiana.

Darwin, C. (2016). Waterfall Model of software development: A sure fire practice for your professional software needs. Diperoleh pada 8 Ogos 2019 daripada https://medium. com/synapse-india/waterfall-model-of-software-development-a-sure-fire-practice-foryour-professional-software-needs-4c8997419800

De Sousa, L., Richter, B., \& Nel, C. (2017). The effect of multimedia use on the teaching and learning of social sciences at tertiary level: A case study. Yesterday \& Today Journal, (17), 1-22.

Faizah, J. (2017). Bahan bantu mengajar (BBM) dalam pengajaran dan pembelajaran (P\&P) di Sekolah Menengah Kebangsaan (SMK) daerah Pontian. Disertasi Master. Johor: Universiti Tun Hussein Onn Malaysia.

Hsu, Y.C., \& Ching, Y.H. (2012). Mobile microblogging: Using Twitter and mobile devices in an online course to promote learning in authentic contexts. The International Review of Research in Open and Distance Learning, 13(4), 211-227.

Johnson, L., Adams, S., \& Cummins, M. (2012). Mobile apps. The NMC horizon report: 2012 higher education edition. Austin, Texas: The New Media Consortium.

Kementerian Pendidikan Malaysia. (2015). Pelan pembangunan pendidikan Malaysia (PPPM) 2015-2025. Putrajaya: Kementerian Pendidikan Malaysia.

Kerski, J. J., Demirci, A., \& Andrew, J. M. (2013). The global landscape of GIS in secondary education. Journal of Geography, 112(6), 232-247.

Nurkaliza Khalid, Hailruddin Jaafar, \& Rafiza Kasbun. (2015). Model pembelajaran aplikasi android "Jamak Qasar Apps" berasaskan elemen multimedia. Proceeding of IC-ITS 2015 e-ISBN: 978-967-0850-07-8 International Conference on Information Technology \& Society, 8-9 June 2015, Kuala Lumpur, Malaysia.

Shamsiah Sidek. (2012). Penggunaan media pengajaran dalam kalangan guru-guru mata pelajaran Geografi di Daerah Batu Pahat, Johor. Tidak diterbitkan. Fakulti Pendidikan Teknokal dan Vokasional, UTHM.

Sharma, Neha. (2019). The beginner's guide to Android: Android architecture. Diperoleh pada 8 Ogos 2019 daripada https://www.edureka.co/blog/beginners-guide-androidarchitecture/

Siti Aminah, S., \& Fazlinda, A.H. (2018). Penggunaan alat bahan bantu mengajar berasaskan multimedia dalam pengajaran dan pembelajaran di Sekolah Menengah Zon Besut. Online Journal for TVET Practitioners. Special Issues: Multidisciplinary research in education. Diperoleh dari from https://publisher.uthm.edu.my/ojs/index.php/ojtp/article/view/4814

Sivakumar, R. (2015). Android Apps in teaching English. Journal of Contemporary Educational Research and Innovation 5(5): 214-219.

Walker, L. (2011). My teacher is an android: Engaging learners through an android application. Proceeding ASCILITE 2011. Hobart Australia. 1269-1274. 